\title{
Difficulties in the Normalization of Aminotransferase Measurement with Enzyme Standards
}

\author{
By A.P. Jansen \\ Dept. Clinical Chemistry, Sint Radboud Hospital, University of Nijmegen, The Netherlands
}

(Received September 20/December 14, 1984)

Summary: Commercial control sera contain varying amounts of pyridoxal-5'-phosphate. Normalization of aminotransferase activity measurement with enzyme'standards' is possible only when pyridoxal-5'-phosphate is added to the reaction medium.

Pyridoxal-5'-phosphate addition should be compulsory in national recommendations.

\section{Schwierigkeiten bei der Kalibrierung von Bestimmungen der Aminotransferasen mit Enzymstandards}

Zusammenfassung: Käufliche Kontrollseren enthalten unterschiedliche Konzentrationen von Pyridoxal-5'phosphat. Eine Normalisierung der Aminotransferase-Aktivitätsmessung mit Enzym'standards' ist nur möglich unter Zugabe von Pyridoxal-5'-phosphat zum Reaktionsmedium.

Pyridoxal-5'-phosphat-Zugabe sollte in nationalen Empfehlungen obligatorisch sein.

\section{Introduction}

In our work on enzyme standards we encountered difficulties in the determination of aspartate aminotransferase $(1,2)$. In contrast to the favourable effect of enzyme standards on the results of other enzyme determinations, the use of standards conferred no benefit in the determination of aspartate aminotransferase. This seemed to be due to deficiencies in the reaction medium. In several methods and recommendations, pyridoxal $=5^{\prime}=$ phosphate is not added to the reaction medium. The old thesis was therefore adopted that pyridoxal- $5^{\prime}$-phosphate is necessary for optimal aspartate aminotransferase catalytic activity; at the same time it was thought that the pyridoxal5 -phosphate content of various control sera and standards is subject to considerable variations. Methods not including pyridoxal- 5 -phosphate in the reaction medium would therefore give different results for serum and standard, compared with methods that include additional pyridoxal-5'-phosphate in the reaction medium. If a serum or standard already contains sufficient pyridoxal-5'-phosphate, then the addition of more pyridoxal-5'-phosphate will have no effect, but when a serum or standard is deficient in pyridoxal-5'-phosphate the addition of the coenzyme will alter the results.

Although many national recommendations for aspartate aminotransferase measurement include pyridoxal-5'-phosphate, addition of the cofactor is not obligatory in the German and Scandinavian recommendations. In the Scandinavian recommendations of 1974 (9) a possible supplementation with pyridoxal-5'-phosphate was suggested especially for aspartate aminotransferase. Special mention was made in that publication of the lack of pyridoxal phosphate in most commercial control sera. The use of pyridoxal-5'-phosphate is therefore not so self evident, not even in the Netherlands, where $48 \%$ of the laboratories do no include it in the reaction medium for aspartate aminotransferase determination, despite strong evidence in the literature $(3-6)$ of the activating effect of pyridoxal-5'-phosphate on aminotransferase.

for enzymes in the Netherlands Quality Assessment programme for clinical chemical hospital laboratories, it is now possible to discriminate for temperature and also, as far as the aminotransferases 
are concerned, for addition of pyridoxal-5'-phosphate.

The problem of the enzyme standard in aspartate aminotransferase determinations has been investigated in a trial of the coupled external/internal program (7) and also in the external scheme.

It was thought worthwhile to call attention once more to the problem of pyridoxal-5'-phosphate supplementation of reaction media for the measurement of aminotransferase catalytic activity, especially for the normalization of enzyme determination with standards.

\section{Materials and Methods}

In the coupled external/internal programme some 70 laboratories analysed, over a period of 40 days, Precinorm U, a bovine serum from Boehringer Mannheim lot no Ch 1-501. Omega, a human serum from Hyland, Travenol, lot no 4833 Y005 BA was used and considered as the enzyme 'standard' in this trial, although the material in fact is not a standard.

In table 1 the codes are given for the different methods used. The pyridoxal-5'-phosphate of serum and standard was measured according to the method described by Westerhuis \& Hafkenscheid (8). In the external quality assessment programme, 4 sera were used for this investigation. Sera I and II are human sera (Ortho, lot nos. X39Y 02B and X40 Y02B). Serum III is a horse serum and serum IV is of human origin (Netherlands Institute of Public Health).

Tab. 1. Method codes for aspartate (ASAT) and alanine aminotransferase (ALAT) determinations.

\begin{tabular}{|c|c|c|c|c|c|c|}
\hline \multicolumn{2}{|l|}{ Code } & \multirow[t]{2}{*}{ Method } & \multirow[t]{2}{*}{ Buffer } & \multirow{2}{*}{$\begin{array}{l}\text { Temperature } \\
\left({ }^{\circ} \mathrm{C}\right)\end{array}$} & \multirow{2}{*}{$\begin{array}{l}\text { Pyridoxal- } \\
5^{\prime} \text {-phosphate } \\
\text { added }\end{array}$} & \multirow[t]{2}{*}{ Reference } \\
\hline ASAT & $:$ ALAT & & & & & \\
\hline 120 & 130 & manual & tris & 25 & yes & \\
\hline 121 & 131 & automated & tris & 25 & yes & \\
\hline 122 & 132 & manual & tris & 25 & no & \\
\hline 123 & 133 & automated & tris & 25 & no & \\
\hline 124 & 134 & manual & phosphate & 25 & no & 10 \\
\hline 125 & 135 & automated & phosphate & 25 & nọ & 10 \\
\hline 126 & 136 & centrifugal analyser & phosphate & 25 & no & 10 \\
\hline 127 & 137 & centrifugal analyser & tris & 30 & yes & $11^{\prime}$ \\
\hline 128 & 138 & manual & tris & 30 & yes & 11 \\
\hline 129 & 139 & automated & tris & 30 & yes & 11 \\
\hline 620 & 630 & manual & tris & 30 & no & \\
\hline 621 & 631 & automated & tris & 30 & no & \\
\hline 622 & 632 & manual & phosphate & 30 & no & \\
\hline 623 & 633 & automated & phosphate & 30 & no & \\
\hline 624 & 634 & manual & tris & 37 & yes.: & \\
\hline 625 & 635 & automated & tris & 37 & yés" & \\
\hline 626 & 636 & manual & tris & 37 & no & \\
\hline 627 & 637 & automated & tris & 37 & no & \\
\hline 628 & 638 & manual & phosphate & 37 & no & \\
\hline 629 & 639 & automated & phosphate & 37 & no & \\
\hline
\end{tabular}

Tab. 2. Catalytic concentrations of aspartate aminotransferase in $U / 1$ in Omega and Boehringer sera. $n$ is the number of participating laboratories. The result per laboratory is the mean of 40 independently performed analyses. Results from internal/external scheme.

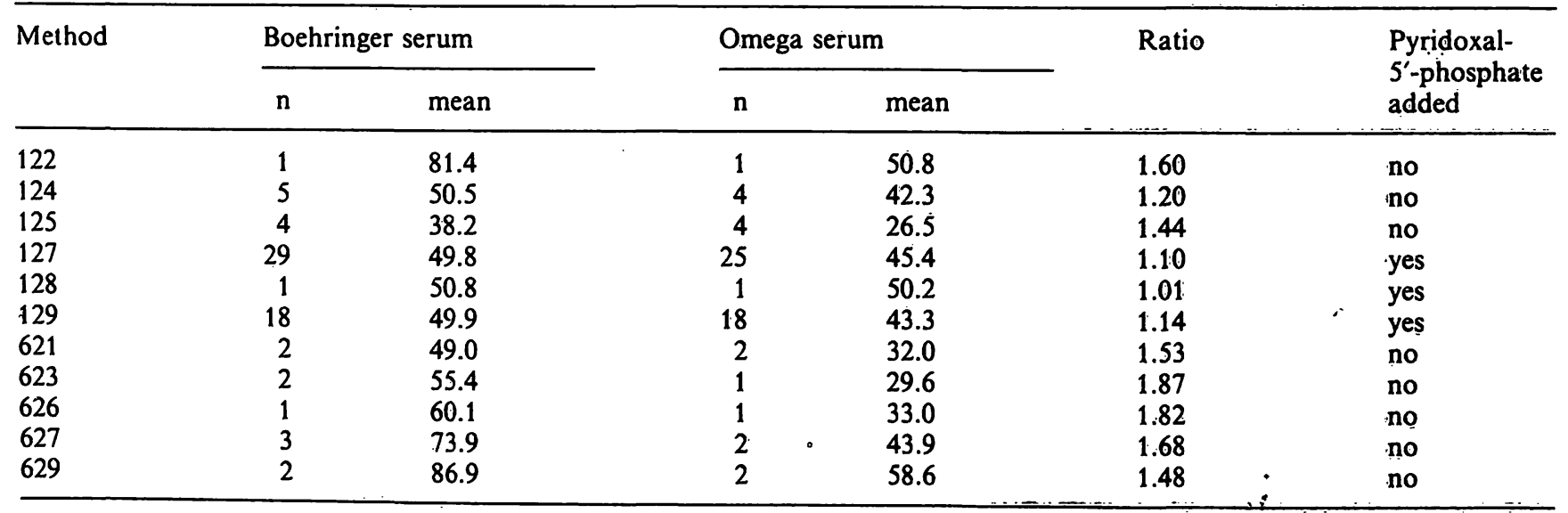




\section{Results}

In table 2 the results are presented for the different methods used in the determination of aspartate aminotransferase with the Boehringer and Omega material. It should be remembered that the result of each laboratory is the average of 40 measurements on different days, so even method results obtained with few laboratories are relevant. In table 3 results are compared for aspartate aminotransferase and alanine aminotransferase measurement by similar methods with and without pyridoxal-5'-phosphate addition. The pyridoxal-5'-phosphate content of the sera is given in table 4 . In table 5 data are presented from two trials of the external quality assessment programme.

\section{Statistical evaluation}

Table 5 shows a comparison of results obtained at the same temperature, but in the presence and absence of pyridoxal-5'-phosphate (Student's t-test).
Tab. 4. Pyridoxal-5'-phosphate content of 6 sera used in this investigation. Serum III and IV were made available by RIVM (Netherlands Institute of Public Health).

\begin{tabular}{lc}
\hline & $\begin{array}{l}\text { Pyridoxal- } \\
5^{\prime} \text {-phosphate } \\
(\mu \mathrm{g} / \mathrm{l})\end{array}$ \\
\hline Omega & 2.9 \\
Boehringer & 110 \\
Serum I Ortho & 11.5 \\
Serum II Ortho & 9.5 \\
Serum III & 108 \\
Serum IV & 156 \\
\hline
\end{tabular}

For aspartate aminotransferase, the results obtained with methods 127,128 and 129 are similar $(p>0.8)$ for both sera I and II.

Results obtained with methods 621 and 128 are not similar $(p<0.001)$.

The same holds for results found with methods 121 and $123(\mathrm{p}<0.001)$ and methods 624 and 627 $(\mathrm{p}<0.001)$.

Tab. 3. Comparison of aspartate (ASAT) and alanine aminotransferase (ALAT) results in U/l with identical methods, with the exception of pyridoxal-5'-phosphate addition ( $\left.\mathrm{P}-5^{\prime}-\mathrm{P}\right)$ to the medium. Results from internal/external scheme.

\begin{tabular}{|c|c|c|c|c|c|c|c|}
\hline \multirow[t]{2}{*}{ Method } & \multirow{2}{*}{$\begin{array}{l}\text { Tem- } \\
\text { perature } \\
\left({ }^{\circ} \mathrm{C}\right)\end{array}$} & \multirow[t]{2}{*}{ Buffer } & \multirow[t]{2}{*}{$P-5^{\prime}-P$} & \multicolumn{2}{|c|}{ Boehringer } & \multicolumn{2}{|l|}{ Omega } \\
\hline & & & & ASAT & ALAT & ASAT & ALAT \\
\hline Centrifugal fast analyser & 30 & tris & yes & 49.8 & 42.2 & 45.4 & 28.9 \\
\hline Automated & 30 & tris & yes & 49.9 & 40.8 & 43.3 & 29.8 \\
\hline Automated & 30 & tris & no & 49.0 & 39.8 & 32.0 & 26.1 \\
\hline
\end{tabular}

Tab. 5. Aminotransferase results in U/l from the Netherlands external quality assessment programme. Serum I, II and IV are of human origin, serum III is a horse serum. Pyridoxal-5'-phosphate was added $(100 \mu \mathrm{g} / \mathrm{l})$ to sera III and IV.

\begin{tabular}{|c|c|c|c|c|c|c|}
\hline \multirow{2}{*}{$\begin{array}{l}\text { Method } \\
\text { code }\end{array}$} & \multirow{2}{*}{$\begin{array}{l}\text { Pyridoxal- } \\
\text { 5'-phosphate } \\
\text { added }\end{array}$} & \multirow{2}{*}{$\begin{array}{l}\text { Tem- } \\
\text { perature } \\
\left({ }^{\circ} \mathrm{C}\right)\end{array}$} & Serum I & Serum II & Serum III & Serum IV \\
\hline & & & $\bar{x} \pm s$ & $\overline{\mathbf{x}} \pm s$ & $\bar{x} \pm s$ & $\overline{\mathbf{x}} \pm \mathrm{s}$ \\
\hline
\end{tabular}

Aspartate aminotraṇs ferase

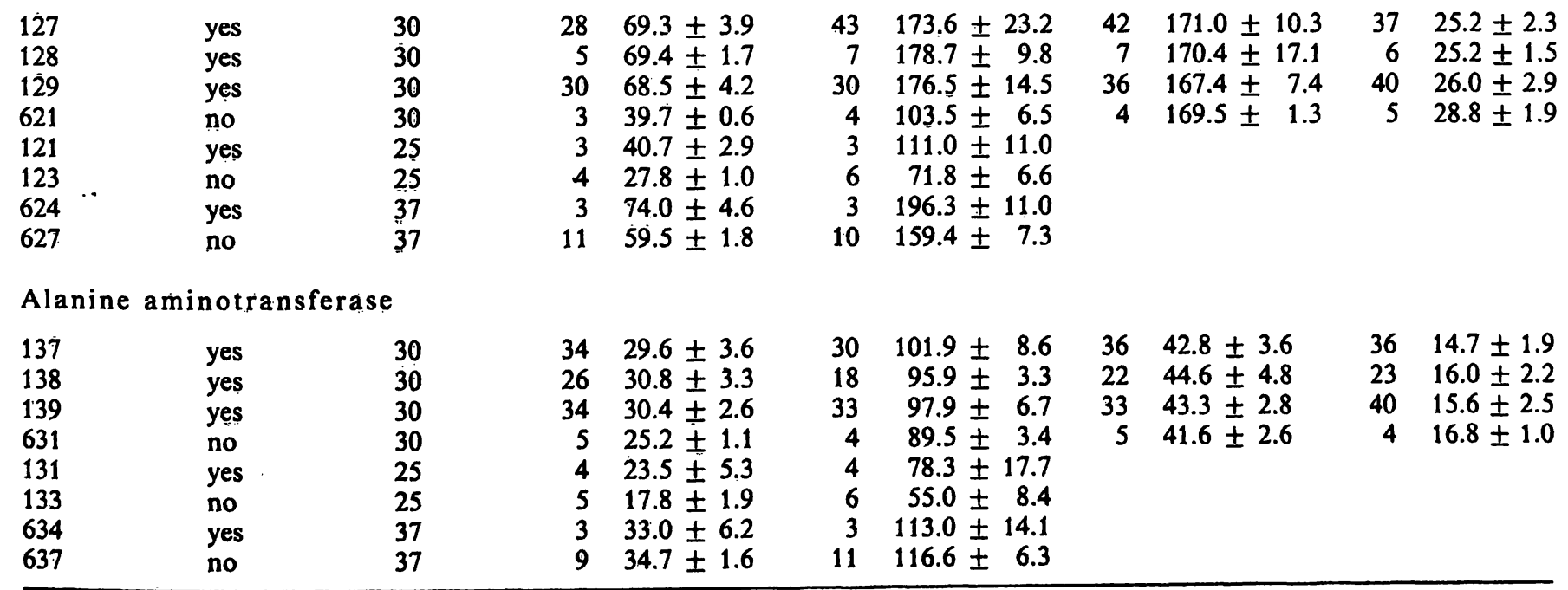


For alanine aminotransferase, the results obtained with methods 127,128 and 129 on the one side differ significantly from those of method $621(\mathrm{p}<0.01)$.

The differences between methods 121 and 123 are significant at the $5 \%$ level $(\mathrm{p}<0.05)$.

No significant differences were observed between results with method 624 and $627(\mathrm{p}<0.2)$.

Tested for the F-distribution the variances were considered equal $(p<0.95)$.

\section{Discussion and Conclusions}

From table 2 it is obvious that $70 \%$ of the laboratories participating in the coupled external/ internal programme use the aspartate aminotransferase method recommended by the NVKC (Netherlands Society for Clinical Chemistry). In contrast to this finding in the external programme, only $47 \%$ of the participants use the recommended method for aspartate aminotransferase, in which pyridoxal-5'-phosphate is added. It is also obvious that the ratio of Boehringer/Omega results is higher when pyridoxal-5'-phosphate is omitted than when it is included.

Consideration of table 3 and 4 makes it clear why the use of a standard not always improves the results of aspartate aminotransferase.

When the pyridoxal-5'-phosphate content of a sample is low, the differences in analytical results between methods including or omitting pyridoxal-5'-phos-

\section{References}

1. Jansen, R. T. P. \& Jansen, A. P. (1983) Ann. Clin. Biochem. $20,52-59$

2. Jansen, A.P. \& Jansen, R. T. P. (1983) Tijdschr. Ned. Ver. Klin. Chemie 8, 48-51.

3. Hamfelt, A. (1966) Scand. J. Clin. Lab. Invest. 18, suppl. 92, $181-188$.

4. Rosalki, S. B. \& Bayoumi, R. A. (1975) Clin. Chim. Acta $59,357-360$.

5. Ury, A. G. \& Chassy, J. R. (1973) Clin. Chem. 19, 140.

6. Hafkenscheid, J. C. M. \& Dijt, C. C. M. (1979) Clin. Chem. $25,55-59$.

7. Jansen, R. T. P. \& Jansen, A.P. (1980) Clin. Chim. Acta $107,185-201$ phate become obvious. However, when the sample does contain a considerable amount of pyridoxal-5'phosphate these differences are eliminated.

Table 3 also shows the results for alanine aminotransferase, which demonstrate that pyridoxal-5'phosphate activation of alanine'aminotransferase is smaller than for aspartate aminotransferase.

Data from the external trials presented in table 5 confirm the statements made above. Again differences in aspartate aminotransferase results occur for different methods when the pyridoxal-5'-phosphate content of serum is low (tab. 5). The effect is demonstrated for different temperatures (serum I and II). In table 5 results are also given for sera containing considerable amounts of pyridoxal- 5 '-phosphate, and it can be seen that methodological effects then disappear (serum IIII and IV).

Too few data were available to show the effects for temperatures other than $30^{\circ} \mathrm{C}$.

These findings seem to contrast with data from the literature $(6,8)$, which report similar sensitivity towards pyridoxal- 5 '-phosphate for both aspartate and alanine aminotransferase activity measurements.

In conclusion it can be stated that recommendations for aminotransferase catalytic activity measurement should include pyridoxal-5'-phosphate in the reaction medium to optimize specificity. Manufacturers of control sera should be advised to add pyridoxal -5 'phosphate to these sera $(50 \mu \mathrm{g} / \mathrm{l})$ in order to achieve comparable analytical results with optimized and deficient methods.
8. Westerhuis, L. W. J. J. M. \& Hafkenscheid, J.C. M. (1983) Clin. Chem. 29, 789-792.

9. Recommended methods for the determination of four enzymes in blood (1974) Scand. J. Clin. Lab. Invest. 33, $291-306$.

10. Empfehlungen der Deutschen Gesellschaft für Klinische Chemie. Standardisierung von Methoden zur Bestimmung von Enzymaktivitäten in biologischen Flüssigkeiten. Experimentelle Begründung der optimierten Standard Bedingungen (1972) Z. Klin. Chem. Klin. Biochem. 10, 182-189.

11. van der Heiden C., Boerma, G. J. M, Bootsma, J., Hafkenscheid, J. C. M., Smit, E. M. \& Spijkers, J. B. F. (1979) Med. Ned. Ver. Klin. Chemie 4, 314 $=320$.

Prof. Dr. A. P. Jansen

Dept. Clin. Chem.

St. Radboud Zièkenhhuis

NL-6525 GA Nijmegen 